\title{
CALIBRATION OF ANGLES OF NOZZLES AND DEPOSITION OF AN AXIAL-FLOW SPRAYER ON DWARF CASHEW
}

\section{RENILDO L. MION ${ }^{1}$, BEATRIZ M. DE SOUSA ${ }^{2}$, IGOR M. CORDEIRO ${ }^{3}$, WEBERTE A. SOMBRA $^{3}$, JOSÉ M. DE L. DUARTE ${ }^{3}$, FIDEL C. B. LUCAS ${ }^{4}$}

\begin{abstract}
The study aimed to determine an optimum angle for the nozzles axial-flow sprayers a deposition for better vertical distribution focused on cashew. In laboratory tests were conducted adjusting the angle of the nozzle axial-flow sprayers. The experimental design was randomized blocks in a $2 \times 3$ factorial with four replications. The treatment for this test were two settings (with and without the adjustment of the angles of the nozzles ) and tree application volumes 273, 699 and $954 \mathrm{~L} \mathrm{ha}^{-1}$. The study was conducted in an orchard of dwarf cashew, with eight years of age. It was concluded that the volumetric distribution profile showed better vertical distribution uniformity when the angles of the nozzles were regulated for the canopy, the adjustment of the angles of the nozzles for the canopy provided greater deposition of droplets, the increased volume of application resulted in higher depositions in the leaves of the crop.
\end{abstract}

KEYWORDS: fruit, deposition, vertical patternator.

\section{CALIBRAÇÃO DOS ÂNGULOS DOS BICOS E A DEPOSIÇÃO DE CALDA DE UM TURBOATOMIZADOR NA CULTURA DO CAJUEIRO-ANÃO}

RESUMO: O estudo teve como objeto determinar melhor angulação para os bicos de um turboatomizador para a deposição de distribuição vertical otimizada e dedicada ao cajueiro-anão. Em laboratório, foram conduzidos os testes de regulagem dos ângulos dos bicos do turboatomizador. Utilizou-se delineamento experimental em blocos casualisados, em esquema fatorial $2 \times 3$, com quatro repetições. Os tratamentos foram duas regulagens (com e sem regulagem dos ângulos dos bicos) e três volumes de aplicação, sendo 273; 699 e 954 L ha- ${ }^{1}$. O estudo a campo foi conduzido em um pomar de cajueiro-anão precoce, com oito anos de idade. Concluiu-se que o perfil de distribuição volumétrico vertical apresentou melhor uniformidade de distribuição quando os ângulos dos bicos foram regulados para a copa da cultura; a regulagem dos ângulos dos bicos para a copa da cultura proporcionou maiores deposições de gotas; o aumento do volume de aplicação proporcionou maiores deposições nas folhas da cultura.

PALAVRAS-CHAVE: fruticultura, deposição, mesa vertical.

\section{INTRODUCTION}

The Dwarf Cashew Crop (Anacardium occidentale L.), in virtue of its social and economic importance on the productive sector, it is spread throughout in almost the entire Brazilian territory; as a result it was inevitable the disorderly expansion of its growth in almost all ecosystems, many which have different environmental characteristics from the original region of this species (OLIVEIRA et al., 2000). In the Brazilian Northeast the dwarf cashew is a crop of high economic and social importance, occupying an area of 670 thousand hectares, which represents $98 \%$ of the planted area in the country, generating income for more than 300 thousand people, with foreign currency reserves superior to 135 million dollars yearly (LEITE, 2010). Recently the cashew culture

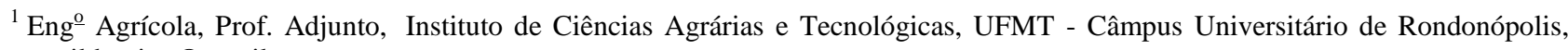
renildomion@gmail.com.

${ }^{2}$ Tecnólogo em Irrigação, Mestre em Engenharia Agrícola, DENA/UFC, Fortaleza - CE.

${ }^{3}$ Pós-graduando em Engenharia Agrícola (Engenharia de Sistemas Agrícolas), DENA/UFC, Fortaleza - CE.

${ }^{4}$ Graduando em Agronomia, UFC, Fortaleza - CE.

Recebido pelo Conselho Editorial em: 8-9-2011
}

Aprovado pelo Conselho Editorial em: 12-3-2012 
have been directed to the utilization of the peduncle as a source of income for small and large producers, and the plague, as it is on the majority of crops, come to depreciate its commercial value.

To avoid losses with great economic consequences the agrochemicals have become an important tool as a protection agent to plants against many types of plagues, propelling the food production (ABHILASH \& SINGH, 2009). With the increasing environmental contamination concern due to the use of agrochemicals, there have been generated efforts to reduce the impact caused by its disordered use, mainly in its application, when considerable amounts of product are placed outside the target area. This way the application technology of agrochemicals have a fundamental role, which the main objective is to place the exact quantity of the active ingredient on the target, with a maximum efficiency and in the more economical possible way, affecting the environment minimally (MATTHEWS, 2002).

In shrubby crops, according to HOLOWNICKI et al. (2000), the turbo atomizers are the most utilized, for being easy to operate and effective in plague and diseases control. However, the authors point that the pulverization with turbo atomizers characterizes as an inefficient process, due to losses surpassing by over half of the phytosanitary products applied.

According to observations done by PERGUER (2004) the pulverization applications in shrubby crops, the spacial distribution of the leaves, fruits and other parts of the plant can vary considerably according to each crop, growth phases, application effects, or other factors. Therefore, the calibration must include an adequate adjustment of the directions of the spray nozzles and the air flows in order to allow a uniform deposition over the entire height of the canopy of the crops.

Various researchers have utilized the vertical patternator as a tool to adjust the spray nozzles angles to the canopy of the crop and to determine the profile of the vertical distribution, contributing to reduce the environmental impact caused by the indiscriminate use of agrochemicals (GIL \& BADIOLA, 2007; PERGHER, 2004). MION et al. (2011) concluded that the air flow influenced on the profile of volumetric distribution to the right as well as to the left of the application, demonstrating the need to direct the spray nozzles to the canopy of the crop.

To minimize this variation, LANDERS (2008) worked altering the angles of the spray nozzles directing them to the top of the grape crop and concluded that the directing reduced the variability and improved the symmetry of the distribution curve on the vertical patternator, stating that the ideal in order to obtain a good uniform distribution of the tail at the moment of the application would be seeking a new layout for the spray nozzles at the extensions. With the presented information this research objected to study the profile of the volumetric distribution and the deposition of droplets with the angles of the spray nozzles from the turbo atomizer varying the volume of pulverization on the dwarf cashew crop.

\section{MATERIAL AND METHODS}

The determination of the distribution profiles for the adjusted and not adjusted nozzles was performed at the Laboratório de Eletrônica e Máquinas Agrícolas (LEMA) and at the Núcleo de Estudos de Máquinas Agrícolas do Semiárido (NEMASA) from Universidade Federal do Ceará, Brazil. To collect the pulverized liquid a droplet collector was built to collect the droplets, made of a rectangular frame measuring $2.90 \mathrm{~m}$ in height, $1.42 \mathrm{~m}$ of width and with side notches every $21 \mathrm{~mm}$, where were mounted collecting plastic gutters. The collecting gutters are horizontal canals with $1.55 \mathrm{~m}$ in length, of a wavy section and internal longitudinal prominence, according to MION et al. (2011). The sides of the frame are open, and the droplet collector was mounted on an iron structure with $1 \mathrm{~m}$ in length and $0.18 \mathrm{~m}$ wide, according to Figure 1.

On the main structure, every ten collecting gutters, were installed funnels projected to the front of the area where the pulverized liquid is captured, working as collectors of water gathered from the gutters, responsible for guiding them to graduated cylinders, by polyethylene hoses of $12.7 \mathrm{~mm}$ in diameter, connected to the exit of the funnel. The collecting gutters were positioned 
inside the structure, with a $12^{\circ}$ declivity, being the first lateral exit to collect the liquid was located after the tenth gutter, and so on.

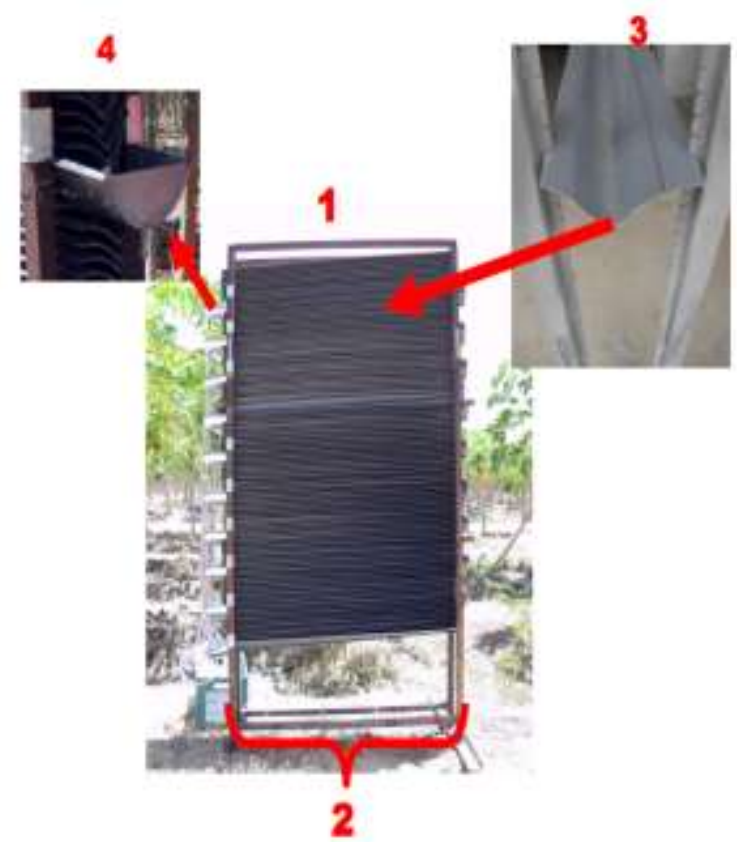

FIGURE 1. Front view of the vertical patternator (1- vertical patternator, 2- iron structure, 3- plastic gutters, 4- zinc funnel).

For the laboratory trials was utilized a turbo atomizer from the manufacturer Jacto, model ARBUS 400 GOLDEN, composed of a $400 \mathrm{~L}$ high density polyethylene tank, graduated level visor, tail agitator by hydraulic return, variable pressure up to $2758 \mathrm{kPa}, \mathrm{JP}-75 \mathrm{pump}$, with capacity of $75 \mathrm{~L} \mathrm{~min}^{-1}$ at $540 \mathrm{rpm}$, actuated by the tractor's shaft which it was attached to, extensions of stainless steel spray nozzles, with 12 nozzles on each side, with individual angle adjustment and individual handle, fan with nylon and fiber glass blades of $85 \mathrm{~m}$ in diameter, generating an average air flow speed of $35 \mathrm{~m} \mathrm{~s}^{-1}$.

The pulverizing system was positioned to a distance of $1.20 \mathrm{~m}$ from the collecting vertical patternator, and $0.75 \mathrm{~m}$ from the ground. The funnels to capture the pulverized liquid were displaced at the following heights from the ground: $0.50 ; 0.75 ; 1.00 ; 1.20 ; 1.40 ; 1.65 ; 1.85 ; 2.10$; 2.30 and $2.55 \mathrm{~m}$. On Figures 2 and 3 are presented the illustrated schematics of the nozzles from the turbo atomizer with the angles without adjustment and with adjustment respectively.
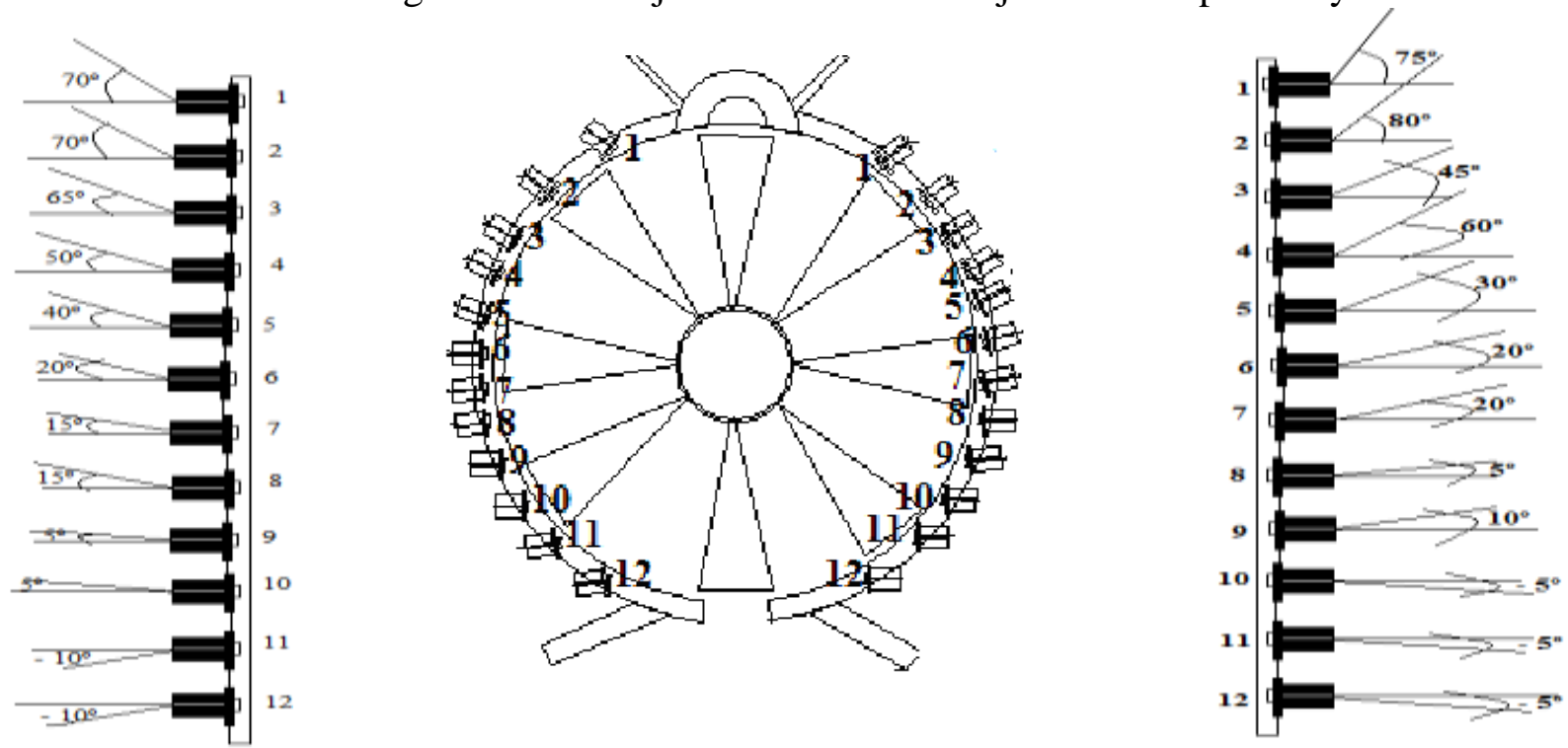

FIGURE 2. Schematic without adjustment of the angles on the turbo atomizer. 

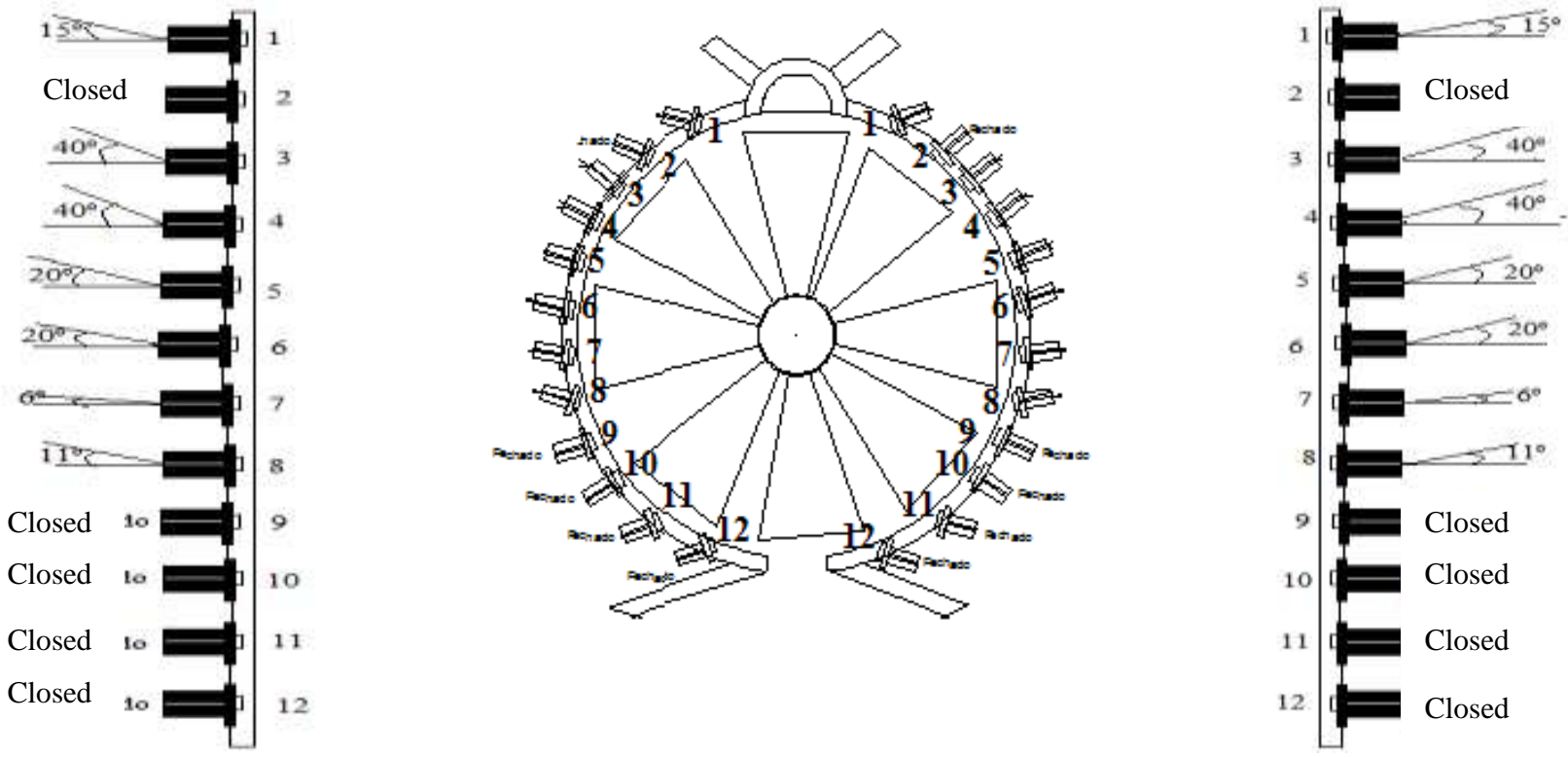

FIGURE 3. Schematic with adjustment of the angles of the turbo atomizer.

To fabricate the curves from the volumetric distribution, it was adopted the collecting time of the liquid of $60 \mathrm{~s}$ for each side, with three repetitions and the average of the volumes collected on the graduated cylinders were plotted in graphics on the Excel 2003 software.

The experimental script adopted was in randomized blocks, on a factorial $2 \times 3$ scheme, with four replications. The treatments for the realization of this experiment were two adjustments (with and without adjustment of the angles of the nozzles) and three volumes of application being 273; 699 and $954 \mathrm{~L} \mathrm{ha}^{-1}$. For being a crop that have being studied very little about the technology of applying chemicals, the volumes were chosen based on the experience that some farmers and technicians that utilized these volumes, however without any study done about deposition.

On the trials were utilized the ceramic tips JA-2 e JA-5, with the empty conic spray, with the pressure of $1.240 \mathrm{kPa}$ on the JA-5 tip and the volume of $954 \mathrm{~L} \mathrm{ha}^{1}$ and the pressure of $620 \mathrm{kPa}$ for the JA-5 and JA-2 tips for the volumes of 273 and $699 \mathrm{~L} \mathrm{ha-}^{-1}$, respectively.

The field study was conducted with the same equipment in a precocious-dwarf cashew crop of 8 years of age, spacing of $8 \mathrm{~m}$ between lines and $8 \mathrm{~m}$ between plants, located in Palhano, state of Ceará, Brazil, with coordinates $4^{\circ} 44^{\prime} 42^{\prime \prime} \mathrm{S}$ and $37^{\circ} 57^{\prime} 32^{\prime \prime} \mathrm{W}$; at the moment the temperature was $32{ }^{\circ} \mathrm{C}$ and the air humidity was $53.7 \%$. The crop had a height of $2.80 \mathrm{~m}$, canopy diameter of $4 \mathrm{~m}$ and $2 \mathrm{~m}$ of height, with leaves and fruits concentrated at the outskirts of the canopy.

For the solution deposition on the leaves of the dwarf cashew crop was utilized a tracer with the dye FD\&C Blue $\mathrm{n}^{\mathrm{o}} 1$ in a concentration of $2 \mathrm{~g}$ per liter of solution, according to the methodology described by PALLADINI (2000).

After pulverization six leaves were collected from each plant, two from the front, two from the sides and two from the back of the plant. Following, each leaf was placed in a plastic bag, identified accordingly to their positions from the collection and placed in a refrigerated environment until they were processed in the laboratory.

For the deposition analysis $50 \mathrm{~mL}$ of distilled water was placed in every plastic bag and then shaken so that there would be removal of the dye from the leaves. Then it was made the reading of absorbance from the solution in all the leaves by a spectrophotometer Ultrospect 2000 Pharmacia, equipped with a filter of $630 \mathrm{~nm}$ wave lengths, according to method developed by PALLADINI (2000). 
To determine the area of each collected leaf was utilized a leaf area (LI-3100, Area Meter, LiCor. ${ }^{\circledR}$, Lincoln, Nebraska, USA). These values of the leaves' areas were used to calculate the solution deposit per area, as shown on eq.(1):

$$
\mathrm{D}=\frac{\mathrm{V}}{\mathrm{A}}
$$

where:

D - deposit of solution on the leaf, $\mathrm{mL} \mathrm{cm}^{-2}$;

$\mathrm{V}$ - volume retained by the target, $\mathrm{mL}$, and

A - leaf area, $\mathrm{cm}^{2}$.

The deposition data from the study was subjected to a variance analysis and the averages were compared by the Tukey test at $5 \%$ probability, using the statistics package ASSISTAT.

\section{RESULTS AND DISCUSSION}

The vertical patternator is used to simulate the canopy of a crop and the profile results for the vertical distribution indicate great variability in the pulverization pattern.

On Figure 4 (C e D) it is possible to observe that the adjustment and the closing of some nozzles allow a better profile distribution compared to the ones that did not have an adjustment. Also that after the adjustment of the angles of the nozzles there was an even volume distribution application to the top of the crop, avoiding losses of the product on the soil. Results observed by PERGHER et al. (2002) show that the variation of the angles of the pulverization nozzles showed as an efficient method for altering the vertical distribution pattern of a turbo atomizer, leading to an improvement on the vertical distribution profile.

LANDERS \& GIL (2006) observed in their studies that the direction of the ascending air flow contributed to the projection of the liquid above the crop without achieving the goal of deposition on the leaves, fruits and the stalk of the crop. This variation can be explained due to the direction of the turbine's rotation from the turbo atomizer that makes the air movement suffers a lateral deflection causing a larger directing of pulverizing solution to the right side, considering the displacement direction of the tractor (BALAN et al., 2006a). Similar results of asymmetrical curves were found by SOMBRA et al. (2010), evaluating different pressures and empty cone nozzle tips and GIL \& BADIOLA (2007), studying different application volumes and quantities of nozzles in a turbo atomizer.

On Figure 4 (C e D) we are able to observe that the adjustment and closing of some nozzles obtained a better profile distribution compared to the ones that were not adjusted, also that after the adjustment of the angles of the nozzles, obtained an uniform application of the volume to the top of the crop, avoiding losses of the product in the soil.

BALAN et al. (2006b) concluded that the original configuration of the pulverizing nozzles on turbo atomizers' extensions isn't always the best one, and the closing or opening of a few nozzles contributed to a more uniform application. 
A

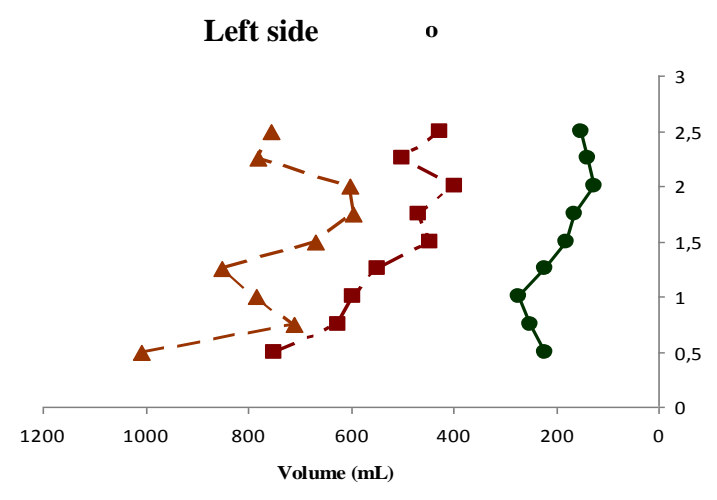

C

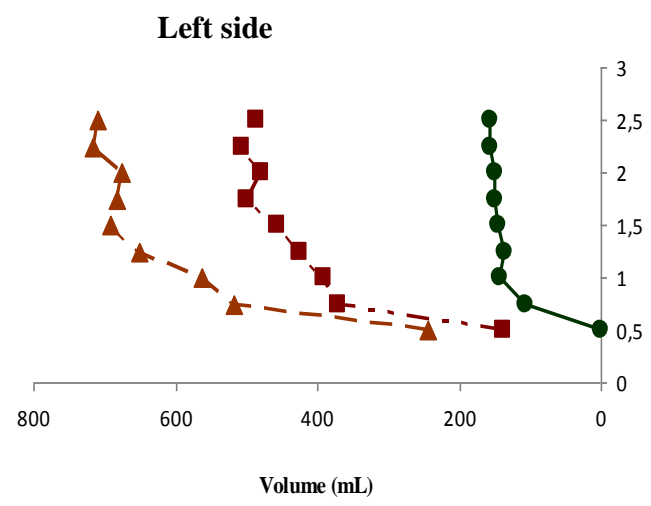

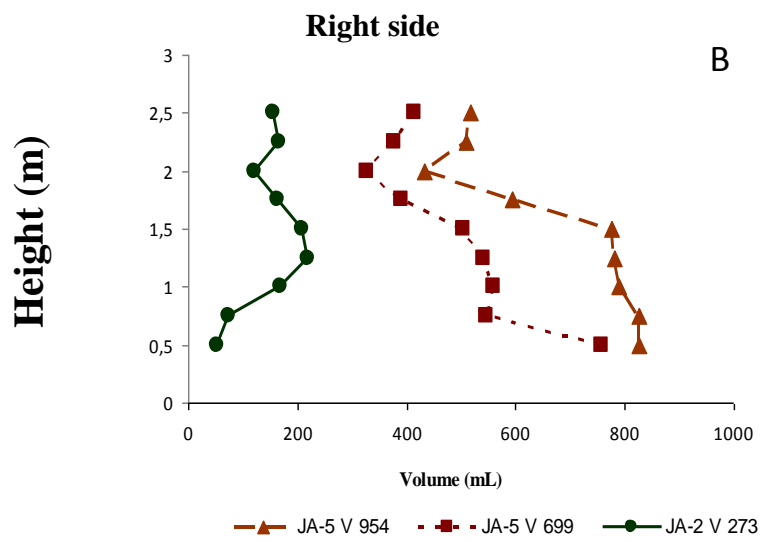

B

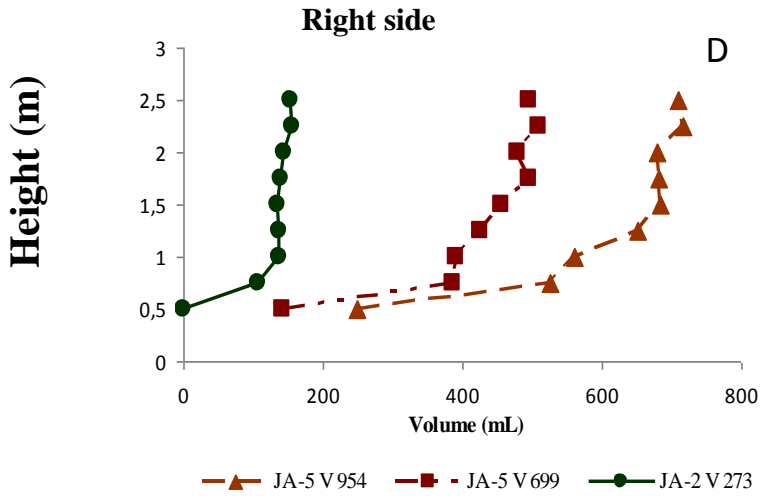

FIGURE 4. Vertical distribution profile without adjustment (A, B) and with adjustment (C, D) of the angles of the nozzles to the canopy of the crop.

On Table 1 it is possible to observe that for the application volume of $273 \mathrm{~L} \mathrm{ha}^{-1}$, the adjustment of the nozzles did not differed statistically, but there was the tendency for the tips adjusted to the canopy of the crop to present bigger deposition. For the deposition of droplets with the volumes of 699 and $954 \mathrm{~L} \mathrm{ha}^{-1}$ notice that the adjustment of the nozzles to the canopy contributes for a larger deposition of droplets on the leaves of the crop, ranging from 60.63 to $42.17 \%$, respectively, for both volumes. This increase on deposition with the orientation of the nozzles is in accordance with the results found FAROOQ \& LANDERS (2004) when was used a vertical patternator to measure the fractioning of the liquid deposited in different heights, with values of $72 \%$ of deposition on the top region when the nozzles were directed to the canopy of the crop.

It is observed that the increase of the volume of the application combined to the directing of the pulverization to the canopy of the crop contributes to the increase of deposition, on the leaves of the crop, acknowledging being an important aspect to the quality of the application, according to reports of the research conducted by BALAN et al. (2006a), BALAN et al (2006b), RAMOS et al. (2007), WISE et al. (2010) e MEWES et al. (2011).

TABLE1. Deposition volume on the leaves $\left(\mu \mathrm{L} \mathrm{cm}^{-2}\right)$ due to adjustments of the angles of the nozzles and the volume of application.

\begin{tabular}{cccc}
\hline \multirow{2}{*}{ Adjustment of the Nozzles } & \multicolumn{3}{c}{ Volumes (L ha-1) } \\
\cline { 2 - 4 } & 273 & 699 & 954 \\
\hline With adjustment & $0.0543 \mathrm{a}$ & $0.2449 \mathrm{a}$ & $0.3749 \mathrm{a}$ \\
\hline Without adjustment & $0.0412 \mathrm{a}$ & $0.0964 \mathrm{~b}$ & $0.2168 \mathrm{~b}$ \\
\hline
\end{tabular}

The averages followed by the same letter do not differ statistically between them by the Tukey test at the level of 5\% of probability. Volumes are quantitative data, which the test $\mathrm{F}$ does not apply. 


\section{CONCLUSIONS}

The volumetric distribution profile showed better distribution pattern when the angles of the nozzles were adjusted for the canopy of the crop. The adjustment of the angles of the nozzles to the canopy of the crop allowed bigger depositions of droplets and the increase in volume of application allowed for bigger depositions on the leaves of the crop.

\section{REFERENCES}

ABHILASH, P.C.; SINGH, N. Pesticide use and application: An Indian scenario. Journal of Hazardous Materials, v.165, p.1-12, 2009.

BALAN, M.G.; ABI SAAB, O.J.G.; SASAKI, E.H. Distribuição da calda na cultura da Videira por turboatomizador com diferentes configurações de pontas. Ciência Rural, Santa Maria, v.36, n.3, p.731-738, 2006a.

BALAN, M.G.; ABI SAAB, O.J.G.; SILVA, C.G. Depósito e perdas de calda em sistema de pulverização com turboatomizador em videira. Engenharia Agrícola, Jaboticabal, v.26, n.2, p.470477, 2006b.

FAROOQ, M.; LANDERS, A.J. Interactive effects of air, liquid and canopies on spray patterns of axial-flow sprayers. In: ASAE/CSAE ANNUAL INTERNATIONAL MEETING, 2004, Ottawa. St. Joseph: ASAE, 2004. (Paper 041001).

GIL, E.; BADIOLA, J. Design and verification of a portable vertical patternator for vineyard sprayer calibration. Applied Engineering in Agriculture, St. Joseph, v.23, n.1, p.35-42, 2007.

HOLOWNICKI, R.; DORUCHOWSKI, G.; SWIECHOWSKI, W.; GODYN, A. Automatic self adjusting air-jet sprayer concept for fruit trees. In: INTERNATIONAL CONFERENCE ON AGRICULTURAL ENGINEERING, 2000, Warwick. Proceedings... 2000. 10 p. (Paper 00053).

LANDERS, A. Improving spraying efficiency. Disponível em:

<www.nysaes.cornell.edu/ent/faculty/landers/pestapp. 2008>. Access: 19 ago. 2011.

LANDERS, A.; GIL, E. Development and validation of a new deflector system to improve pesticide application in New York and Pennsylvania grape production areas. In: INTERNATIONAL CONFERENCE ON AGRICULTURAL ENGINEERING, 2006, Warwick. Proceedings... 2006. 10 p. (Paper 061001).

LEITE, K.N. Análise econômica da resposta do cajueiro anão precoce BRS 189 aos fatores de produção água e adubo potássico. 2000. 99 f. Dissertação (Mestrado em Engenharia Agrícola) Universidade Federal do Ceará, Fortaleza, 2010.

MATTHEWS, G.A. The application of chemicals for plant disease control. In: WALLER, J.M.; LENNÉ, J.M.; WALLER, S.J. Plant pathologist's pocketbook. Londres: CAB, p.345-353. 2002.

MEWES, W.L.C.; TEIXEIRA, M.M.; FERNANDES, H.C.; CECON, P.R.; ALVARENGA, C.B. Deposição de calda em eucalipto, utilizando pulverização pneumática. Bioscience Journal, Uberlândia, v.27, n.2, p.283-288, 2011.

MION, R.L.; SOMBRA, W.A.; DUARTE, J.M. de L.; NASCIMENTO, E.M.S.; VILIOTTI, C.A.; LUCAS, F.C.B.; MONTE, C.A. Uso de mesa vertical como parâmetro para regulagens de turboatomizadores. Engenharia Agrícola, Jaboticabal, v.31, n.2, p.352-358, 2011.

OLIVEIRA, F.N.S.; AQUINO, A.R.L. de; LIMA, A.A.C. Correção da acidez e adubação mineral em solos cerrados cultivados com cajueiro anão precoce enxertado. Fortaleza: Embrapa Agroindústria Tropical, 2000. 31 p. (Circular Técnica, n.5).

PALLADINI, L.A. Metodologia para avaliação da deposição em pulverizações. 2000. 111 f. Tese (Doutorado em Proteção de Plantas) - Universidade Estadual Paulista, Faculdade de Ciências Agronômicas, Botucatu, 2000. 
PERGHER, G. Field evaluation of a calibration method for air-assisted sprayers involving the use of a vertical patternator. Crop Protection, Guildford, v.23, n.5, p.437-466, 2004.

PERGHER, G.; BALSARI, P.; CERRUTO, E.; VIERI, M. The relationship between vertical spray patterns from airassisted sprayers and foliar deposits in vine canopies. Aspects of Applied Biology, Edinburgh, v.66, p.323-330, 2002.

RAMOS, H.H.; YANAI, K.; CORRÊA, I.M.; BASSANEZI, R.B.; GARCIA, L.C. Características da pulverização em citros em função do volume de calda aplicado com turbopulverizador. Engenharia Agrícola, Jaboticabal, v.27, p.56-65, 2007. Número Especial.

SOMBRA, W.A.; MION, R.L.; DANTAS, M.J.F.; VILLIOTI, C.A.; NASCIMENTO, E.M.S. Avaliação do perfil vertical de distribuição volumétrica de um turboatomizador. In: FURLANI, C.E.A.; SILVA, R.P. da; ROSALEN, D.L.; SILVA, J.G.F. da; REIS, E.F. dos; VENTURIN, J.B.A. Engenharia agrícola e o desenvolvimento das propriedades familiares. Jaboticabal: Associação Brasileira de Engenharia Agrícola, 2010. 1 CD-ROM.

WISE, J.C.; JENKINS, P.E.; SCHILDER, A.M.C.; VANDERVOORT, C.; ISAACS, R. Sprayer type and water volume influence pesticide deposition and control of insect pests and diseases in juice grapes. Crop Protection, Washington, v.29, p.378-385, 2010. 